\title{
Development of PISA-Like mathematics tasks design of change and relationship content to assess mathematical representation skills
}

\author{
Noor Aini ${ }^{1,2}$, Suparman ${ }^{2 *}$ \\ ${ }^{1}$ SMP Muhammadiyah 1 Kalasan, Sleman, Yogyakarta, Indonesia \\ ${ }^{2}$ Universitas Ahmad Dahlan, Kota Yogyakarta, Yogyakarta, Indonesia \\ *Corresponding author: suparman@pmat.uad.ac.id
}

DOI: https://doi.org/10.37134/ajatel.vol9.no1.3.2019

Published: 14 June 2019

\begin{abstract}
This study aims to analyze the need for developing PISA type problems in change and relationship content designed to assess mathematical representation abilities. This research is a type of development research by adapting the Tessmer development model. This research was conducted in two stages, namely the preliminary stage, namely preparation and design, then the formative evaluation phase which included self evaluation, prototyping, small group, and field tests. This research is limited to the prototyping stage. The subjects of this study were SMK Diponegoro Depok students, Indonesia. The instrument of data collection consists of observation guidelines, interview guidelines, documentation sheets, and questionnaires. Data was analyzed by qualitative and quantitative techniques. The results showed that the design of the PISA type that had been developed was declared valid, so that it could be expanded at the stage of developing small groups and field tests. Thus, the design of the PISA type on change and relationship content can be used by students, both with low, medium, and high abilities according to the needs of students in the era of globalization.
\end{abstract}

Keywords: change and relationship, design, PISA, representation, assessment

\section{INTRODUCTION}

Mathematics has a lot of connection in daily life that involves activities experienced by humans, so it requires understanding literacy in completing it. Mathematical literacy can help someone to understand the role or function of mathematics in everyday life. Therefore, literacy skills are so important. Mathematical literacy in the Program for International Student Assessment (PISA) aims to determine the mathematical literacy of students aged 15 years. Students are said to have mathematical literacy if students can formulate, apply, and interpret mathematics in various contexts that include mathematical reasoning and using mathematical concepts, procedures, facts, and tools to describe, explain, and predict phenomena in everyday life (OECD, 2017).

The twenty first century is characterized as the information era that emphasizes the importance of enhancing student's literacy at all levels of education from kindergarten to the end of high school. This is in contrast to previous years in which skills and the carrying out of algorithms were considered as the main objectives of mathematics education (Mevarech \& Fan, 2018). Therefore, the development of mathematical questions in the era of globalization refers to the PISA problem.

The PISA problem is developed based on four mathematical content, namely: (1) change and relationships, (2) space and shape, (3) quantity, and (4) uncertainty and data (OECD, 2010). According to Ojose (2011) states that change and relationship content are events in various settings such as the growth of organisms, music, the cycle of seasons, patterns of weather, and economic conditions. This category is related to aspects of mathematical content in the curriculum, namely function and algebra. Whereas for 15 year olds the function and algebra are challenging to understand material. Though this material is the basis of the material that will be obtained later. 
The low ability of students to solve mathematical problems of the type of PISA can be seen from the ranking of Indonesia in the PISA itself. The results of the PISA study published by the OECD, 2015 put Indonesia in position 63 of 70 countries. According to Wijaya (2015), the PISA results from 2000-2015 repeatedly showed that Indonesian students in completing context based tasks were also still low. The analysis conducted by Stacey (2011) suggests that Indonesian students have more difficulty working on PISA questions in change and relationship content (algebra and measurement) compared to the problem of quantity, space and shape, uncertainty and data (numbers, geometry, and data), especially in the achievement of hot levels. Therefore, from this, Indonesian students should be accustomed to working on PISA type math problems in learning, especially on change content and relationships (Ahyan, Zulkardi, \& Darmawijoyo, 2014).

One other factor that causes mathematical literacy of Indonesian students is lower than other countries because they are not used to working on mathematical problems with high thinking skills (Oktiningrum, Zulkardi, \& Hartono, 2016). While in solving mathematical problems, students need to observe and find out patterns or rules specific to the problem. That is, students need to formulate a concrete application problem to model it into mathematical equations. In the formulation process, students must have several representation skills to articulate the same problem in different forms (Hwang, Chen, Dung, \& Yang, 2007).

The purpose of learning mathematics is no longer only emphasizing the improvement of learning outcomes, but also is expected to improve abilities: (1) mathematical communication; (2) mathematical reasoning; (3) mathematical problem solving; (4) mathematical connections; (5) mathematical representation (NCTM, 2000).

One of the mathematical abilities that students need to master is the ability of representation. Mathematical representation is defined as various forms of representation that students use to interpret problems (Ainsworth, 2006). Representative ability is one component of the standard process in the Principles and Standards for School Mathematics in addition to problem solving ability, reasoning, communication and connection (NCTM, 2000).

According to Jones (in Asmara, 2014), there are three reasons why representation is one of the standard processes, namely: (1) fluency in translating between different types of representations is an essential ability that students need to have to develop a concept and think mathematically; (2) the mathematical ideas presented by the teacher through various representations will have a considerable influence in learning mathematics; and (3) students need practice in building their own representations so that students have the ability and understanding of right and flexible concepts that can be used in problem solving.

The inclusion of representation as a standard component of the process in Principles and Standards for School Mathematics is reasonable because to think mathematically and communicate mathematical ideas, one needs to represent them in various ways. Thinking is a process of producing new mental representations through information transformation that involves complex interactions between mental attributes such as assessment, abstraction, imagination, and problem solving (Solso, 1991). Besides, it cannot be denied that objects in mathematics are all abstract and that to learn and understand abstract ideas requires representation. The mathematical abilities used in the assessment of mathematical processes in PISA in can be seen in Table 1 (OECD, 2010).

The explanation above shows how important representation skills are in mathematics learning. The use of various representations has an important role in mathematics learning (Cai \& Lester, 2005), especially in helping to understand and interpret mathematical concepts in various representations (Pape \& Tchoshanov, 2001). Rahmawati, Hidayanto and Anwar (2017) stated that generally in mathematics, representation is only a complement in solving mathematical problems. This leads to minimal representation capabilities. The weakness of mathematical representation ability is caused by difficulties in bridging representation and change from one representation to another (Yerushalmy, 1997). Thus, the use of representation deserves serious attention in learning. 
Table 1. The mathematical abilities in OECD

\begin{tabular}{|c|c|}
\hline Mathematical Abilities & Description \\
\hline Communication & $\begin{array}{l}\text { Students feel some challenges and are stimulated to recognize and } \\
\text { understand problems. Reading, coding and interpreting statements, } \\
\text { questions, tasks or objects that allow students to form a mental model of the } \\
\text { situation which is an important step in understanding, explaining, and } \\
\text { formulating problems. During the problem solving process, it needs to be } \\
\text { summarized and presented. Then after the solution is found, the problem } \\
\text { solver needs to present the solution obtained, and conduct a verification of } \\
\text { the solution. }\end{array}$ \\
\hline Mathematizing & $\begin{array}{l}\text { The term mathematical is used to describe basic mathematical activities } \\
\text { involved in the form of transforming problems defined in everyday life into } \\
\text { mathematical forms (which include structures, concepts, making } \\
\text { assumptions, and or formulating models), or interpreting, evaluating } \\
\text { mathematical results or mathematical models in conjunction with contextual } \\
\text { problems. }\end{array}$ \\
\hline Representation & $\begin{array}{l}\text { In this representation ability, students represent the results in the form of } \\
\text { graphs, tables, diagrams, drawings, equations, formulas, textual } \\
\text { descriptions, and concrete material. }\end{array}$ \\
\hline Reasoning and Argument & $\begin{array}{l}\text { This ability involves student's ability to reason logically to explore and } \\
\text { connect problems so that they make their conclusions, justifying their } \\
\text { solutions. (alphabetically) }\end{array}$ \\
\hline $\begin{array}{l}\text { Devising Strategies for Solving } \\
\text { Problems }\end{array}$ & $\begin{array}{l}\text { This ability involves students to recognize, formulate, and solve problems. } \\
\text { This is characterized by the ability to plan strategies that will be used to } \\
\text { solve problems mathematically. }\end{array}$ \\
\hline $\begin{array}{l}\text { Using symbolic, formal, and } \\
\text { technical language, and } \\
\text { operations }\end{array}$ & $\begin{array}{l}\text { This involves the ability of students to understand, interpret, manipulate, } \\
\text { and use mathematical symbols in problem solving. }\end{array}$ \\
\hline Using Mathematical Tools & $\begin{array}{l}\text { This involves the ability of students to use mathematical tools such as } \\
\text { measuring instruments, calculators, computers, and so on. }\end{array}$ \\
\hline
\end{tabular}

According to Bruner (1966), the conceptual development process is a formation of a representation system and in learning it is divided into three development processes involving active, iconic, and symbolic representations. Yanti, Amin, and Sulaiman (2018) suggests some indicators of representation, namely presenting data or information from representation to representations of diagrams, graphs, or tables, making drawings to clarify problems and facilitate their resolution, solving problems involving mathematical expressions, and writing steps to solving problems math with words. Complex problems will be much simpler if using representations that are following the problem given, if the construction of representation is wrong, then the problem will be difficult to solve (Noto, Hartono, \& Sundawan, 2016). Lewis and Mayer (in Chen, Lee, \& Hsu, 2015) show that most difficulties in problem solving occur at the representation stage. If students can understand the various forms of the conversion process for mathematical representation, they will be able to understand the mathematical concepts involved.

Thus, mathematical representations are depictions, translations, disclosures, mining, or modeling, conceptual ideas in mathematics, and relationships including those included in certain situations that are displayed by students in various forms to obtain clarity of meaning, show understanding or find solutions to problems they face. Therefore, the researchers tried to develop PISAlike mathematics tasks of change and relationship content, so that they were expected to be able to assess student's mathematical representation abilities in the PISA study. The development of PISA-like mathematics tasks conducted by researchers is still in the stages of designing, self evaluation, and prototyping (expert reviews and one-to-one). 


\section{METHODS}

This research is a type of development research by adapting the Tessmer development model. According to Tessmer in Nizar, Putri, and Zulkardi (2018) this research was conducted in two stages, namely the preliminary stage, namely preparation and design, then the formative evaluation phase which included self evaluation, prototyping (expert reviews, one to one and small group) and field tests. These stages can be seen in Figure 1 (Van den Akker, 1999).

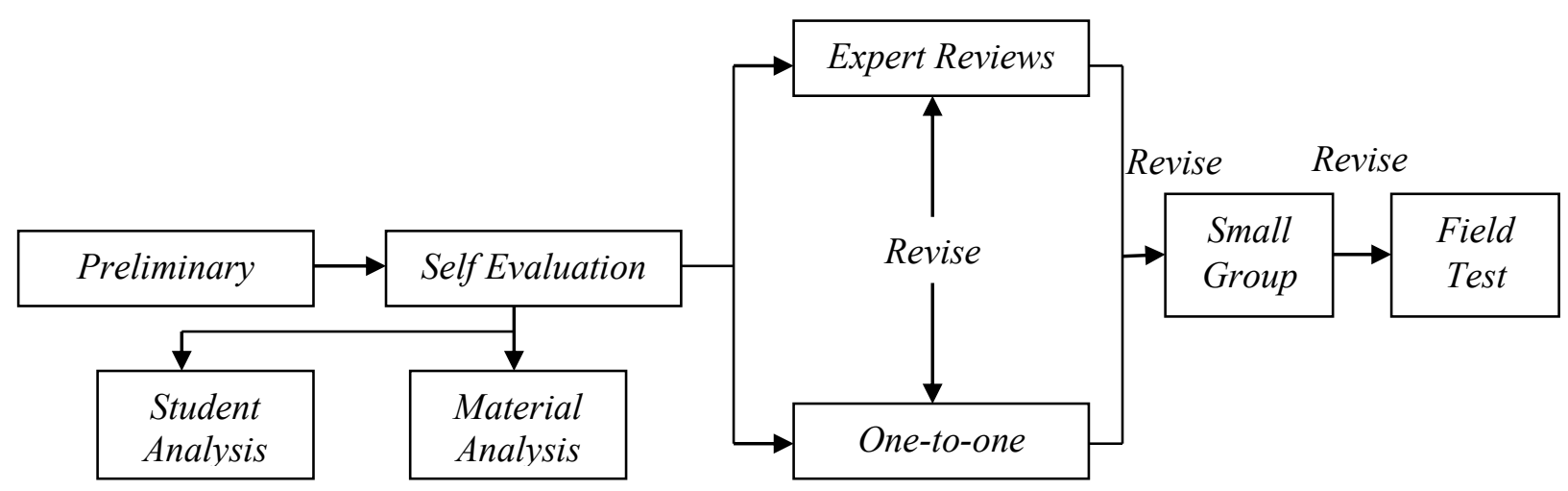

Figure 1. Overview of the research stages

The instrument of data collection consists of observation guidelines, interview guidelines, documentation sheets. Data is analyzed by qualitative techniques. Furthermore, this study produced PISA-like mathematics tasks that fit the needs of students in the era of globalization. Meanwhile, the subjects in the study were students of SMK Diponegoro, Depok, Yogyakarta. Following the formulation of the problem proposed in the background, research is limited to the stages of designing, self evaluation, and prototyping (expert reviews and one-to-one).

\section{RESULTS AND DISCUSSION}

In this stage it is divided into 2 stages, namely preliminary stage and formative evaluation stage.

\section{Step 1: Preliminary Stage}

At this stage, literature is collected relating to the development of PISA-like mathematics tasks of change and relationship content to assess mathematical representation skills. Also, several activities were also carried out such as contacting school principals and mathematics teachers at the school to be used as research locations and arranging research schedules and collaborative procedures with classroom teachers to be used as research sites. At this stage, researchers also designed grids, question cards, and scoring guidelines that were in accordance with the characteristics of the PISA problem, especially in content change and relationship with indicators of mathematical representation ability.

\section{Step 2: Formative Evaluation Stage}

In this stage it is divided into 2 stages, namely self evaluation and prototyping.

\section{Self Evaluation}

In this self evaluation, the researcher analyzes the students who will be used as subjects in the study both regarding academic competence and overall student character. Student analysis is an analysis of the characteristics of students following the design of developing PISA-like mathematics tasks of change and relationship content. The characteristics in question include the criteria for age, class level criteria, and criteria for many students who are the subject of research. 
Furthermore, the researcher also analyzes the subject matter or material related to Change and Relationship content that is adjusted to the Core Competencies and Basic Competencies of Curriculum 2013, namely in algebraic material designed to assess mathematical representation skills.

The development of a conceptual framework is done by designing a question grid. While the level of capability in PISA consists of 6 levels, namely the highest level is level 6 and the lowest level is level 1. However, analyzing the ability of Indonesian students to solve PISA questions change and relationship content reviewed by Julie, Sanjaya, and Anggoro (2017) revealed that student's mathematical abilities that can be achieved up to level 2 amounted to $38,89 \%$, so it can be concluded that the average mathematical ability of students has not been able to reach level 3 and above. Therefore, the researcher limits the development of PISA type math problems change and relationship content at levels $3,4,5$, and 6 , so that many of the minimum questions that must be made are 4 questions.

However, to anticipate any questions that are eliminated after validation by the validators, it is necessary to develop each of the 3 questions at each level. Based on that consideration, it was decided to develop 12 questions. One of these questions was inspired by the PISA 2015 problem with the context unit "Blue Power Plant" presented in Figure 2.

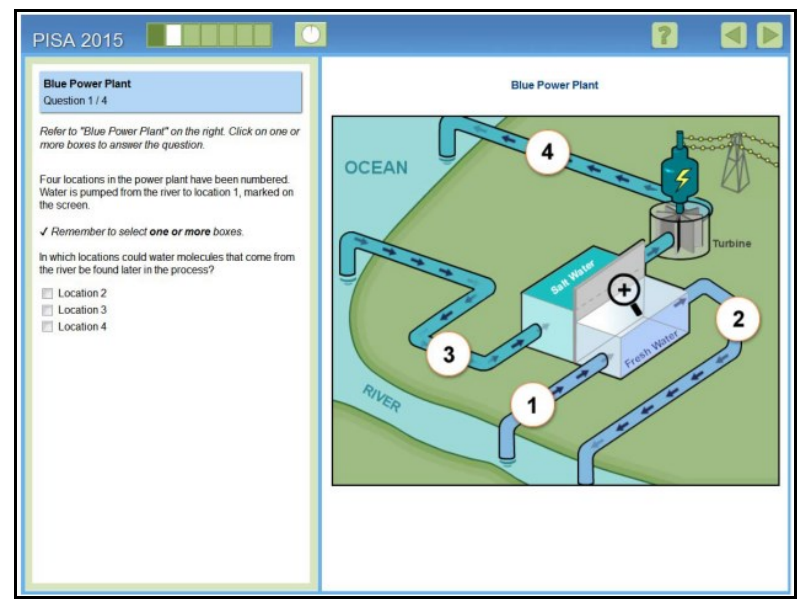

Figure 2. PISA 2015 mathematical tasks context "Blue Power Plant"

The author conducts the paraphrase method to obtain new questions and change data from statements on specific questions. The paraphrase method for obtaining new questions is done by reformulating the problem to a different mathematical domain.

In this problem, students must apply their understanding of how water flows through the power plant presented in the diagram to identify Location 2 and Location 4 containing water molecules from the river. Competencies in the question will be paraphrased into change and relationship content. While the method of changing data from statements on specific questions is by adding a representation of formulas to compare information and determine the values associated with other information. Furthermore, in question 12, questions will be made with content change and relationship with one of them contextualizing occupation and employing processes. Next is the design of the questions that will be made with the prediction of level 5 which is then referred to as prototype 1 as presented in Figure 3.

In the context unit of the " Motif of Solo Slobog Batik", there is a wide and broad pattern statement to look for many motifs. This statement of pattern and size is used to connect some other information so students can estimate the number of motifs that can be formed in batik cloth. The statement in the context unit "Motif of Solo Slobog Batik" is what makes the question classified as change and relationship content.

The context unit "Motif of Solo Slobog Batik" presents a problem about batik cloth which consists of motifs, pieces of cloth, and others. Such topics are discussed in seismology. Because this includes the subject of work, the above questions are included in the context of Occupation. Next, in the question with the context unit "Motif of Solo Slobog Batik" presented above, students must be able to identify and combine information on many motifs with a broad size of fabric, then apply the information in the form of equations and inequalities to make conclusions. Therefore, the process of applying is the main focus in this matter. 


\section{"SOLO SLOBOG BATIK CLOTH MOTIF"}

The picture below is one example of a variety of Solo batik, namely batik Slobog.

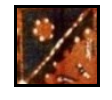

Piece 1

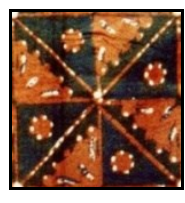

Piece 2

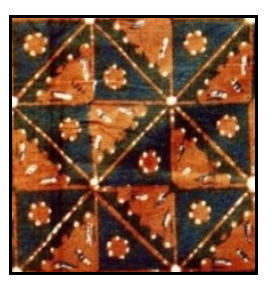

Piece 3

Source : Womantalk.com

Information :

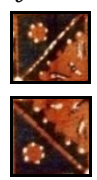

$$
\begin{aligned}
& =\text { motif } 1 \\
& =\text { motif } 2
\end{aligned}
$$

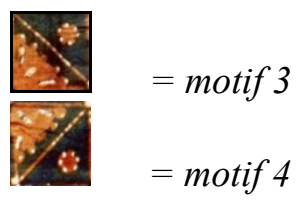

Slobog batik has a geometric motif. The shape is squares and diagonally separated. On one side of the motif that is separated by a line, there is a circle surrounded by six dots. For fabrics with an area of $36 \mathrm{~cm}^{2}$, painted with 1 motif, then for fabrics with an area of $144 \mathrm{~cm}^{2}$ painted with 4 motifs, and so on following the pattern of the image above.

By following the pattern in the picture above. For example, many motifs $1=a$, many motifs $2=$ $b$, many motifs $3=c$, many motifs $1=d$, pieces to $=n$, and area of fabric $=L$. When given a statement $n$ $=6$, then $L=1296 \mathrm{~cm}^{2}, a>b$, and $c=d$, is that statement true? Show your reason.

Figure 3. Prototype 1.

Judging from the mathematical abilities involved, communication skills are needed to identify and combine information on motive patterns about many motifs and the broad size of fabrics. Besides, students also need mathematical skills, namely making mathematical models of equations and linear inequalities. Furthermore, the ability of representation is also needed in comparing the forms of equations and inequalities to determine many motives based on the width of the fabric. The reasoning and argument skills are also needed in combining information in the form of equations and inequalities, broad concepts, and patterns of motives in making conclusions. In finding a direct strategy by using information on text and questions in making conclusions, students need to choose step by step to find a solution. Finally, students also need to do mathematical procedures in using statements $n=6$, then $\mathrm{L}=$ $1296 \mathrm{~cm}^{2}, \mathrm{a}>\mathrm{b}$, and $\mathrm{c}=\mathrm{d}$. This ability is to use symbols $\mathrm{n}, \mathrm{L}, \mathrm{a}, \mathrm{b}, \mathrm{c}$, and $\mathrm{d}$ in making conclusions.

Next, the researcher evaluates and examines the questions that have been made including the question grid, scoring guidelines, and so on that have contained indicators of mathematical representation abilities. After this is done, the first prototype is formed.

\section{Prototyping}

In the expert review stage, the first prototype was validated by Anggit P., M.Pd as Ahmad Dahlan University lecturer and Darto, S.Pd. as a Mathematics teacher who currently serves as Head of SMP N 3 Depok. The results of the calculation of the validation sheet by the validator are shown in Table 2 .

Table 2. Results of validation sheet calculation.

\begin{tabular}{|c|c|c|c|}
\hline No. & Validator & Total Score & Qualitative Criteria \\
\hline
\end{tabular}




\begin{tabular}{|l|l|l|c|}
\hline 1. & Anggit P., M.Pd & 44 & Valid \\
\hline 2. & Darto, S.Pd. & 48 & Valid \\
\hline \multicolumn{2}{|c|}{ Average } & 46 & Valid \\
\hline
\end{tabular}

It can be seen in Table 2 that the average total validity of the PISA type math problem in content change and relationship is 46 . The results of the calculation of the validation sheet are in the validity criteria as shown in Table 3.

Table 3. Results of validation sheet calculation.

\begin{tabular}{|c|c|c|}
\hline No. & Score & Qualitative Criteria \\
\hline 1. & $\bar{X}>50,4$ & Very Valid \\
\hline 2. & $40,8<\bar{X} \leq 50,4$ & Valid \\
\hline 3. & $31,2<\bar{X} \leq 40,8$ & Enough \\
\hline 4. & $21,6<\bar{X} \leq 31,2$ & Less \\
\hline
\end{tabular}

From Table 3, the results of the validation sheet calculation show that the validity criteria are $40,8<\bar{X} \leq 50,4$, so the design of the mathematical type PISA developed is valid. Because prototype 1 has been declared valid, the prototype 1 must be revised and the revised results are called prototypes 2 . Revisions are made based on the comments given by both validators as a whole and comments on each question. Following are the overall comments from the validator presented in Table 4.

Table 4. Results of validation sheet calculation.

\begin{tabular}{|c|l|l|}
\hline No. & \multicolumn{1}{|c|}{ Comments and Suggestions for Improving } & \multicolumn{1}{c|}{ Revised Decisions } \\
\hline 1. & $\begin{array}{l}\text { Overall in the aspect of content is good, but } \\
\text { more information is described again about the } \\
\text { indicators of the ability of mathematical } \\
\text { representation on each question. }\end{array}$ & $\begin{array}{l}\text { Revision of the addition of information about } \\
\text { indicators of mathematical representation } \\
\text { ability on each question. }\end{array}$ \\
\hline 2. & $\begin{array}{l}\text { In the construct aspects of each question is } \\
\text { good. }\end{array}$ & $\begin{array}{l}\text { In a good construct aspect is maintained and } \\
\text { corrected. }\end{array}$ \\
\hline 3. & $\begin{array}{l}\text { The language used in the question needs to be } \\
\text { adjusted again with Enhanced Spelling. }\end{array}$ & $\begin{array}{l}\text { Improving the Enhanced Spelling problem on } \\
\text { the questions developed. }\end{array}$ \\
\hline 4. & $\begin{array}{l}\text { The use of sentences on the question needs to } \\
\text { be corrected in such a way that is easily } \\
\text { understood by students. }\end{array}$ & $\begin{array}{l}\text { Revision of the language of sentence sentences } \\
\text { that are easily understood by students. }\end{array}$ \\
\hline
\end{tabular}

In the one-to-one stage, 3 non-research subjects (high, medium and low ability students) were asked to work on the draft prototype 1, then give comments and responses freely. Next, the researcher acts as a facilitator who observes and helps students who have difficulty when solving the problem. This stage is done with the aim to see the flow of student's thinking on the question and to find out the difficulties of students in understanding and solving problems. The results of the observation analysis show that students are able to understand and solve existing problems. The results of one student's answers can be seen in Figure 4. 

representation skills

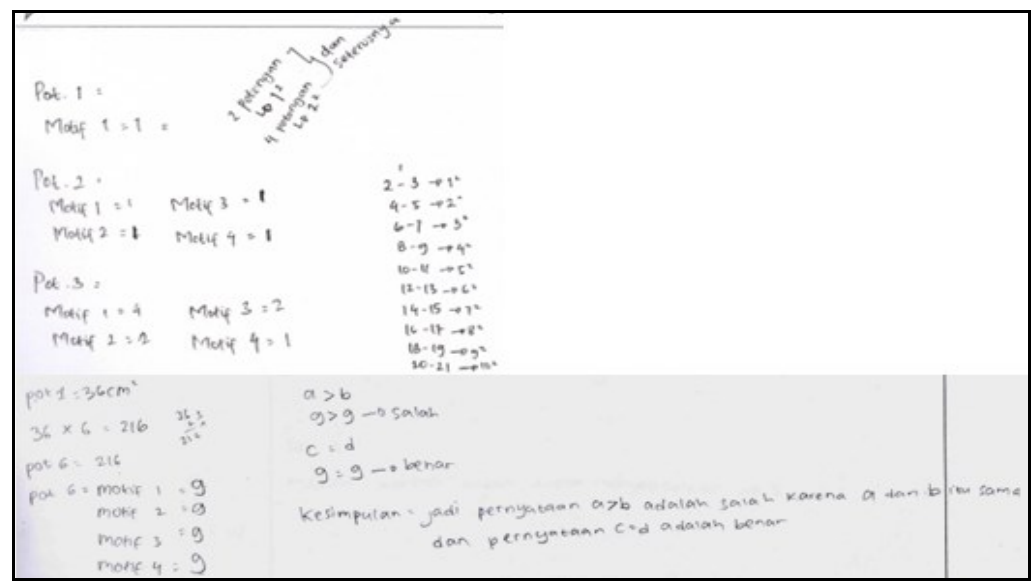

Figure 4. The Student Answer on Task

Based on Figure 4, it can be seen that students determine the motive for the next piece based on the information in the question. Students do calculations based on the area and pattern formed, then compare them in the form of equations and inequalities. Then, the results of the student's answers were analyzed by looking at the guidelines for scoring student's representation skills based on the 2015 PISA framework as presented in Table 5.

Table 5. Guidelines for Scoring Mathematical Representation Skills

\begin{tabular}{|c|c|c|}
\hline Assessed Indicators & Response to the Problem & Score \\
\hline \multicolumn{3}{|c|}{ Formulate } \\
\hline \multirow[t]{3}{*}{$\begin{array}{l}\text { Make mathematical representations } \\
\text { of real world information. }\end{array}$} & $\begin{array}{l}\text { Cannot make mathematical representations of real world } \\
\text { information. }\end{array}$ & 0 \\
\hline & $\begin{array}{l}\text { Can make mathematical representations of real-world } \\
\text { information, but still not complete. }\end{array}$ & 1 \\
\hline & $\begin{array}{l}\text { Can make a complete mathematical representation of real- } \\
\text { world information. }\end{array}$ & 2 \\
\hline \multicolumn{3}{|c|}{ Employe } \\
\hline \multirow{3}{*}{$\begin{array}{l}\text { Connect various kinds of } \\
\text { representations when solving } \\
\text { problems. }\end{array}$} & $\begin{array}{l}\text { Cannot connect various kinds of representations when } \\
\text { solving problems. }\end{array}$ & 0 \\
\hline & $\begin{array}{l}\text { Can connect various kinds of representations when } \\
\text { solving problems, but still not complete. }\end{array}$ & 1 \\
\hline & $\begin{array}{l}\text { Can connect various kinds of representations when } \\
\text { solving problems completely. }\end{array}$ & 2 \\
\hline \multirow{3}{*}{$\begin{array}{l}\text { Use a variety of representations in } \\
\text { problem solving. }\end{array}$} & Cannot use various representations in problem solving. & 0 \\
\hline & $\begin{array}{l}\text { Can use various kinds of representations in problem } \\
\text { solving, but not yet complete. }\end{array}$ & 1 \\
\hline & $\begin{array}{l}\text { Can use a variety of representations in solving problems } \\
\text { completely and correctly. }\end{array}$ & 2 \\
\hline \multicolumn{3}{|c|}{ Interprate } \\
\hline \multirow[t]{3}{*}{$\begin{array}{l}\text { Interpret mathematical results in a } \\
\text { form of representation. }\end{array}$} & $\begin{array}{l}\text { Cannot interpret mathematical results in a form of } \\
\text { representation. }\end{array}$ & 0 \\
\hline & $\begin{array}{l}\text { Can interpret mathematical results in a form of } \\
\text { representation, but still not complete. }\end{array}$ & 1 \\
\hline & $\begin{array}{l}\text { Can interpret mathematical results in a complete form of } \\
\text { representation. }\end{array}$ & 2 \\
\hline \multirow[t]{2}{*}{$\begin{array}{l}\text { Compare two or more } \\
\text { representations related to the } \\
\text { situation. }\end{array}$} & $\begin{array}{l}\text { Cannot compare two or more representations related to } \\
\text { the situation. }\end{array}$ & 0 \\
\hline & $\begin{array}{l}\text { Can compare two or more representations related to the } \\
\text { situation, but still not complete. }\end{array}$ & 1 \\
\hline
\end{tabular}




\begin{tabular}{|l|l|c|}
\hline & $\begin{array}{l}\text { Can compare two or more representations that relate to } \\
\text { the situation completely. }\end{array}$ & 2 \\
\hline $\begin{array}{l}\text { Evaluate two or more } \\
\text { representations related to the } \\
\text { situation. }\end{array}$ & $\begin{array}{l}\text { Cannot evaluate two or more representations related to } \\
\text { the situation. }\end{array}$ & $\begin{array}{l}\text { Can evaluate two or more representations related to the } \\
\text { situation, but still not complete. }\end{array}$ \\
\hline & $\begin{array}{l}\text { Can evaluate two or more representations that relate to the } \\
\text { situation completely. }\end{array}$ & 2 \\
\hline
\end{tabular}

Next, based on the comments given by students, the researcher made several changes. These changes are only language that has multiple interpretations so that the sentence needs to be clarified. After going through the expert reviews and one-to-one stages, the first prototype can be said to be valid.

\section{CONCLUSION}

The development of the PISA-like mathematics tasks design of change and relationship content to assess mathematical representation skills has gone through a process of analyzing analysis, both student analysis and material analysis, self evaluation, expert review, and one-to-one. The results of the development of the design of the tasks are declared valid and are ready to enter the stages of small group and field tests as follow-up research. In the small group stage, the first prototype that has been revised will be tested on 6 non-research subjects. Then in the field test stage, the revised prototype of the small group stage was tested on the research subject students to assess the ability of mathematical representation.

\section{REFERENCES}

Ahyan, S., Zulkardi, Z., \& Darmawijoyo, D. (2014). Developing Mathematics Problems Based on PISA Level of Change and Relationships Content. Journal on Mathematics Education, 5(1), 47-56.

Ainsworth, S. (2006). DeFT: A conceptual framework for considering learning with multiple representations. Learning and instruction, 16(3), 183-198.

Asmara, A. (2014). Mathematical Representation Ability And Self Confidence Students Through Realistic Mathematics Approach. Proceeding in International Seminar on Innovation in Mathematics and Mathematics Education 1st ISIM-MED 2014 "Innovation and Technology for Mathematics and Mathematics Education" Department of Mathematics Education,Yogyakarta State University Yogyakarta.

Bruner, J. S. (1966). Toward a theory of instruction (Vol. 59). Harvard University Press.

Cai, J., \& Lester Jr, F. K. (2005). Solution representations and pedagogical representations in Chinese and US classrooms. The Journal of Mathematical Behavior, 24(3-4), 221-237.

Chen, M. J., Lee, C. Y., \& Hsu, W. C. (2015). Influence of mathematical representation and mathematics selfefficacy on the learning effectiveness of fifth graders in pattern reasoning. International Journal of Learning, Teaching and Educational Research, 13(1), 1-16.

Hwang, W. Y., Chen, N. S., Dung, J. J., \& Yang, Y. L. (2007). Multiple representation skills and creativity effects on mathematical problem solving using a multimedia whiteboard system. Journal of Educational Technology \& Society, 10(2), 191-212.

Julie, H., Sanjaya, F., \& Anggoro, A. Y. (2017, September). The student's ability in mathematical literacy for the quantity, and the change and relationship problems on the PISA adaptation test. In Journal of Physics: Conference Series (Vol. 890, No. 1, p. 012089). IOP Publishing.

Lewis, A. B., \& Mayer, R. E. (1987). Student's miscomprehension of relational statements in arithmetic word problems. Journal of Educational psychology, 79(4), 363.

Mevarech, Z. R., \& Fan, L. (2018). Cognition, Metacognition, and Mathematics Literacy. In Cognition, Metacognition, and Culture in STEM Education (pp. 261-278). Cham, Switzerland: Springer.

National Council of Teacher of Mathematics. (2000). Principles and Standards for School Mathematics. Reston, VA: NCTM.

Nizar, H., Putri, R.I.I., \& Zulkardi, Z. (2018). Development of PISA-Like Mathematics Problems with Football and Table Tennis Contexts in The 2018 Asian Games. Journal on Mathematics Education, 9(2). 
Development of PISA-Like mathematics tasks design of change and relationship content to assess mathematical representation skills

Noto, M. S., Hartono, W., \& Sundawan, D. (2016). Analysis of students mathematical representation and connection on analytical geometry subject. Infinity Journal, 5(2), 99-108.

OECD. (2010). PISA 2012 Mathematics Framework. Paris: OECD Publishing.

OECD.(2017). PISA 2015 Assessment and Analytical Framework: Science, Reading, Mathematic, Financial Literacy and Collaborative Problem Solving, revised edition, PISA. Paris: OECD Publishing.

Ojose, B. (2011). Mathematics literacy: Are we able to put the mathematics we learn into everyday use. Journal of Mathematics Education, 4(1), 89-100.

Oktiningrum, W., Zulkardi, Z., \& Hartono, Y. (2016). Developing PISA-like Mathematics Task with Indonesia Natural and Cultural Heritage as Context to Assess Students Mathematical Literacy. Journal on Mathematics Education, 7(1), 1-8.

Pape, S.J., \& Tchoshanov, M.A. (2001). The role of representation (s) in developing mathematical understanding. Theory into practice, 40(2), 118-127.

Rahmawati, D., Hidayanto, E., \& Anwar, R.B. (2017). Process of Mathematical Representation Translation from Verbal into Graphic. International Electronic Journal of Mathematics Education, 12(3), 367-381.

Solso, R. L. (1991). Cognitive psychology. Allyn \& Bacon.

Stacey, K. (2011). The PISA view of mathematical literacy in Indonesia. Journal on Mathematics Education, 2(2), 95-126.

Van den Akker, J. (1999). Principles and methods of development research. In Design approaches and tools in education and training (pp. 1-14). Springer Netherlands.

Wijaya, A. (2015). Context-based mathematics tasks in Indonesia: Toward better practice and achievement. Utrecht University.

Yanti, Y.R., Amin, S.M., \& Sulaiman, R. (2018). Representation of Students in Solving Simultaneous Linear Equation Problems Based on Multiple Intelligence. In Journal of Physics: Conference Series (Vol. 947, No. 1, p. 012038). IOP Publishing.

Yerushalmy, M. (1997). Designing representations: Reasoning about functions of two variables. Journal for Research in Mathematics Education, 28(4), 431-466. 